4. Synthesis between arts and «non- arts.» The four levels of synthesis identified by us are interconnected by means of direct conditionality. The complexity and specificity of each level are determined not only by the quantitative combination of characteristic features of this level, which are integrated in the synthesis, but also by the sum of synthetic indicators of the previous level (or levels).

It is possible to clearly distinguish the concepts of types, kinds and genres of art. The type is a morphological structure, which is formed as a result of the immanent development of expressive means and forms. The kind is a functional system created by the interaction of art forms with the environment of various origins, both social and material. The genre is a content structure that reveals sensory perception and a certain form of judgment.

\title{
References:
}

1. Malishev, Yu. (2002). Problema sinteza iskusstv v sovremennoy estetike [The problem of synthesis of arts in modern aesthetics]. Ferents List i problemy sinteza iskusstv: Sb. nauchnykh trudov / Sost. G. I. Ganzburg. Pod obshchey red. T. B. Verkinoy. Kharkov: RA - Caravel, pp. 38-54.

\section{INTONATION AND INTONEMENT: TERMINOLOGICAL ASPECT}

\section{Zhang Jiaohua ${ }^{1}$}

DOI: https://doi.org/10.30525/978-9934-588-39-6-23

It is known that intonement is a specific sound process, which involves, on the one hand, the source of sound (vocal chords, musical instrument), and the human brain on the other. At the same time, the quality of intonement depends on the activity of the human central nervous system, because the brain acts as a source of physiological impulses, which have a direct impact on the choice of means of musical expression, including dynamics, register, duration, timbre, etc. However, qualitative intonement is impossible without the active participation of emotional and mental activity of the performer himself, and his ability to manifest and sound expression of his own professional, life, intellectual, spiritual and moral experience. Due to this, intonement acquires sense, persuasiveness, emotional saturation, meets the author's idea and style requirements. That is, the brain induces a certain source of sound to the beginning of the sound process, while the intellect fills it with content. In joint activity of brain and intellect, sound energy is

${ }^{1}$ A.S. Makarenko Sumy State Pedagogical University, Ukraine 
also generated, thanks to which all available space is filled, triggering the immediate response of the people in it.

The study of the notion of «intonation» is impossible without considering the notion of «intonement». However, the philosophical and artistic fields interpret these cultural phenomena in different ways. It is known that the term «intonement» comes from the verb form of the latter: intonate - to pronounce (sound) with a certain intonation. It is important to note that the use of these concepts is not limited only to musicology, musical art. They are also related to areas of other arts, primarily those related to the original syncretic form of culture, which included plastic, music and word. For example, the concept of «intonement» can be used by the specialists whose activities are directly related to the word (theatre, poetry, etc.); it can be used in the meaning of «plastic intonement» by persons whose activities are related to the dance art, as well as by athletes in sports such as rhythmic gymnastics, figure skating, etc.

It is important to note that the very definition of «intonement» is somewhat problematic. Thus, despite the rather active use of the term, all dictionaries give only its verb form «intonate» - to execute or pronounce with a certain intonation. At the same time, the noun «intonement» is not found not only in dictionaries, but also in the studies which are related on the actual problem and actively use this term. However, another term has been defined «intonation». S. Ozhegov's dictionary has three definitions: «1. Increasing or decreasing the tone of voice during pronunciation. 2. Manner of pronunciation, which expresses certain feelings of the speaker, tone. 3. Accuracy of voice sounding when singing or musical instrument while playing» [4, p. 224]. As we can see, intonation is often understood as a manner of pronunciation, which expresses the speaker's feelings, his attitude towards the subject of speech, peculiarities of his mental state and state of mind at the moment. The intonation in speech represents its rhythmic and melodic structure. In the process of learning, the phenomenon of «intonation» acquired several meanings:

- intonation is a unique rhythmic and melodic structure of languages and gestures of all the nations in the world; alternation of raises and decreases, accelerations and decelerations of tones when pronouncing language constructions. Each nation has its own special intonations in speech and expressive movements, special character of pronunciation of words and sentences in oral speech, specific character of historically formed expressive gestures and movements, traditional songs and ancient music;

- each person is a bearer of a special, inherent intonation, which colours his or her language and individual mimic and bodily movements, as well as pauses (expressive stops). 
The voice of each person is brightly individual. Nevertheless, it is quite difficult to characterize its uniqueness in each individual person: whether it is the voice of a person who is not professionally focused on the expressiveness of his voice in everyday speech, or the voice of a talented actor, whose language and intonations were specially formed by the directors and the actor himself.

A. Artaud (1896-1948), a French writer, theatre director and innovator of theatrical language, describing his «Theatre of cruelty», actually discussed any statement as a process of intonation. At the same time, according to A. Artaud, «words will be used in a truly magical sense, depending not only on their meaning, but also on their form, their sensual emanation» [2]. Of course, this was about the meaning of the intonation.

P. Bart (1915-1980) - French philosopher and literary critic, according to whom language is not a simple instrument of content, he himself actively produces this content. R. Bart noted that the voice is the «intimate signature of the actor» [3];

- intonation is a special cultural sign in rhetoric, as well as in musical and theatrical art, where the director, actor and conductor, lecturers and speakers, singers and musicians create standards of intonation culture and control the conformity of the played or executed word or gesture. By the peculiarities of a person's intonation of speech and gestures, one can judge about the cultural environment to which he or she belongs.

According to the opinion of the linguist A. Potebnia (1835-1891), the word may undergo changes that lead to the loss of its figurativeness: «As thought with the help of the word is idealized and freed from the influence of direct sensual perceptions that oppress and crush it, the word loses its figurativeness» [5, p. 154]. In this case, the word is also deprived of the intonation power of influence; in this case, the word certainly «thickens thoughts» [5, p. 155], and the thickening of thoughts is promoted by the accompanying sign system of intonations, which emphasizes the spoken words.

In Soviet musicology, these terms were introduced by the founder of intonation theory, academician Boris Asafiev [1]. In the works of the scientist the studied term is applied in two meanings. Thus, the first one has a close connection with the structural formation of sound making: «Musical intonation - comprehension of existing sounds into a system of sound relations precisely fixed by memory: tones and tones» [1, p. 198], in contrast to the speech intonation: "Speech intonation is a comprehension of nonmusically fixed sounds that have not been stabilized in musical quantities or constant relations of sounds that have become tones» [1, p. 198]. 
The second meaning that B. Asafiev puts into the concept of «intonation» is intonation as sound. The author considers three factors that are essential for melodic formation - «distance, direction (height limits), the degree of melody (the distribution of breathing power in a given sound, that is, the factor of dynamic order)» $[1$, p. 199]. As we can see, the first two factors reveal the structural meaning, the third one - figurative and articulation-expressive, which is connected with sound filling, sound formation, sound extraction, and therefore is closer to the notion of «intonation».

Intonation is a fundamental and universal phenomenon in the system of musical culture, because music shows itself only in the process of sounding, and the qualitative side of intonation determines certain patterns and features in musical culture: style features, traditions, the specificity of instrumental and vocal sounding, the level of performing skills of an instrumentalist, vocalist, etc. Musical intonation performs the same functions as spoken speech. It is capable, at the level of emotional perception and with the help of expressive intonation in combination with a complex of other expressive means, to «voice» an idea, convey the content of a musical work and transmit other important information.

By intonation we mean the musical and sound process that is to be understood, including how sounds are played and shaped, and the sound itself. Through intonation, you can create and convey the necessary expressive and emotional atmosphere, highlighting the most important semantic moments of sound expression. At the same time, intonation is inseparable from metrorhythmic organization of sound tissue.

\section{References:}

1. Asafiev, B. (1971). Muzykal'naya forma kak protsess [Musical form as a process]. Leningrad: Music. (in Russian)

2. Arto, A. (2019). Teatr i yego dvoynik [Theater and its double]. Moscow: ABCdesign. (in Russian)

3. Bart, R. (1989). Izbrannyye raboty. Semiotika. Poetika [Selected Works. Semiotics. Poetics]. Moscow: Progress. (in Russian)

4. Ozhegov, S. (1983). Slovar' russkogo yazyka [Dictionary of the Russian language]. Moscow: Russkiy yazyk. (in Russian)

5. Potebnya, A. (1993). Mysl' i yazyk [Thought and language]. Kiev: SINTO. (in Russian) 